\title{
Eucharistic Reconciliation: Reconciling Broken Selves by Consuming Christ's Broken Body
}

\author{
Megan Heeder \\ Boston College School of Theology and Ministry (Brighton, MA)
}

\begin{abstract}
The Eucharist, the healing Body of Christ, is a major source of grace paramount to the process of reconciliation. Paradoxically, for those who suffer from eating disorders, a prime source of grace is found in the Eucharist, a broken Body whose effects are imparted through eating. Exploring the reconciliation of one who struggles with eating disorders to herself, others (the Church) and the divine via the Eucharist's grace is a largely unexplored area rife with hope. Eucharistic grace has the potential to bear great fruit in the process of recovery, reminding the person who she is, that for which she is created, the depth of Christ's love, and her communal belonging. These graces respond to areas psychology identifies as problematic for those with eating disorders; recovery requires a reconciliation back to the self and others, especially the body of the Church, and carries implications for the Church's vocation of love.
\end{abstract}

\section{Text}

Entering into the conversation between eucharistic grace and the broken bodies, the misshapen realities of those who suffer from eating disorders offers the opportunity to explore a facet of healing grace which is often forgotten in the discussion of what it takes for someone to recover from an eating disorder. Healing does not come merely through changing a set of behaviors; rather, it is the inexplicable changing of a vision, effected by Christ's broken eucharistic Body. The Eucharist is a prime source of divine grace which has the power to heal eating disorders' unintelligible power of distortion through grace. While mysterious, it is clear that grace is a divine gift, moving humans toward the good and sustaining that movement in accord with their free will. St. Thomas Aquinas' treatment of unifying eucharistic grace provides a foothold for exploring the Eucharist's power to heal the broken selves of those who suffer from eating disorders by restoring the sacred act of eating, along with the self, to and through the eucharistic and ecclesial Body of Christ. 


\section{HEEDER：EUCHARISTIC RECONCILIATION}

In order to comprehend the wounds of one with an eating disorder, which eucharistic grace can heal, it is important to understand the context of this woundedness. Extensive research on eating disorders reveals a myriad of causes, many of which are interconnected: environment, athletic or artistic involvement, personality, trauma (especially abuse), and even genetics. Often, medical or psychological treatments of eating disorders focus on these elements, and not without reason. Yet an insidious cause of eating disorders is the culture in which the sufferer lives. The ideals of someone with an eating disorder commonly conflate weight and worthideals of thinness become the measure of worth - and therefore weight and happiness become linked. As a result of this conflation and the "ideal" of skinniness reigning supreme, suffers adopt a rigid adhesion to eating certain foods so as to avoid binges, dichotomous reasoning such as "If I gain one pound I will spiral and gain 10," or a personalization of the eating disorder experience (to the extent that the sufferer is embarrassed to be seen eating, as if the experience of eating itself is inherently shameful). ${ }^{1}$ Indeed, modern culture exists in an altered reality which few consciously acknowledge; nearly every photo, video, or other image is altered to enhance the beauty of its subjects. This retouched culture which values beauty that is slender and firm, without any extraneous "bulges," is the milieu from which eating disorder ideals have been born and is that which feeds them. According to Susan Bordo's analysis, it is not a matter of the sufferer misunderstanding reality, viewing herself $f^{2}$ as fat when she is thin. In fact, "the anorectic does not 'misperceive' her body; rather, she has learned all too well the dominant cultural standards of how to perceive." ${ }^{3}$ For through cultural disciplines of self-modification (dieting, makeup, fashion, even surgical alteration), among other factors, "we continue to memorize on our bodies the feel and conviction of lack, of insufficiency, of never being good enough. ${ }^{4}$ When the wounds of past experiences, a current struggle with eating disorders, and/or a culture which teaches directly and indirectly that the bodies people have are not enough alter the vision of those with eating disorders, the EucharistJesus-waits to offer grace that can help heal the scars that result from eating disorders and bodily misperceptions.

Bordo details three "axes" which help define the fractured vision of the sufferer, a vision that the Eucharist seeks to restore. First, the dualistic axis, which describes the fragmentation of the body into the material versus the spiritual (or bodily versus mental), contains four basic features which, according to Bordo,

${ }^{1}$ Susan Bordo, Unbearable Weight: Feminism, Western Culture, and the Body, 10th ed. (Berkeley: University of California Press, 2003), 58. Susan Bordo is a leading scholar in the field of body studies.

${ }^{2}$ While women are not the only sufferers of eating disorders, statistically they are the most affected group, so the female pronoun will be used throughout this paper.

${ }^{3}$ Bordo, 57.

${ }^{4}$ Bordo, 166. 
"comprise the basic body imagery of the anorectic." The body is experienced as "alien, as the not-self, the not-me," but rather as something "nailed" to the self. It is akin to Descartes' description of the material body as being "ontologically distinct from [the] inner self." Images from Plato, Descartes, and Augustine illustrate the feeling of the body as an experience of "confinement and limitation...from which the soul, will, or mind struggles to escape." As Plato describes it, the body exerts a downward pull, dragging one down from otherwise elevated experiences and possibilities. The body is decisively cast as "the enemy...the source of obscurity and confusion in our thinking." And lastly, the body is experienced as "the locus of all that threatens our attempts at control." This "becomes an incitement to battle the unruly forces of the body, to show it who is boss." 7 The influence of the post-Enlightenment dualist axis moves the sufferer to the believe that " $[t]$ he only way to win this no-win game is to go beyond control, to kill off the body's spontaneities entirely - that is, to cease to experience our hungers and desires." ${ }^{8}$ While recalling that eating disorders are mental and physical illnesses, this "debilitating affliction," is "quite often a highly conscious and articulate scheme of images and associations" even "virtually a metaphysics."

The second and third axes also cry out for graced healing. The control axis identifies eating as the single sector of life in which one has complete control; the ability to ignore excruciating pain or physical complications is proof of how one has mastered her body, sustained by the exhilaration of watching numbers on the scale drop. ${ }^{10}$ Bordo quotes a patient who explains her experience by which "[y]ou make of your own body your very own kingdom where you are the tyrant, the absolute dictator." 11 The gender-power axis identifies a longing to achieve an appropriate sexual and romantic ideal, as dictated by modern cultural norms, ${ }^{12}$ a response to the heart's deepest longing for love which it fears it will never find; anorectic women often speak of feeling like they are "too much"- they demand too much from those around them as they beg for love and exude too much emotion, take up too much space and eat too much food. ${ }^{13}$ However, "each hour, each minute spent in anxious pursuit of that ideal (for it does not come naturally to most mature women) is in fact time and energy taken from inner development and social achievement...the obsession with slenderness is hopelessly counterproductive"14_

\footnotetext{
${ }^{5}$ Bordo's writing focuses on anorexia, although these axes are not limited to this particular eating disorder.

${ }^{6}$ Bordo, 144.

${ }^{7}$ Bordo, 145 .

${ }^{8}$ Bordo, 146.

${ }^{9}$ Bordo, 147.

${ }^{10}$ Bordo, 149.

${ }^{11}$ Bordo, 150.

${ }^{12}$ Bordo, 154.

${ }^{13}$ Bordo, 160.

${ }^{14}$ Bordo, 160.
} 
not only for the woman herself but also for the community at large. Not only is the woman's energy wasted as she fights her very self, exhaustively counting calories, exercising, or even binging and purging, but her affliction becomes all-encompassing. The fight against herself swallows her, binding her into an ingrown vision so all-consuming and self-centered that she struggles to look outward. Instead, she isolates herself so as to better channel all of her energy —all of herself - into this process of proving herself worthy, stripping away, subjecting her body so that she arrives at a locus of total control resulting in the perfection that brings (what is paradoxically eternally elusive when suffering from an eating disorder) rest and happiness.

The picture of those who suffer with eating disorders is infinitely more complex than it might seem; it is more than just a single-minded obsession leading to a medical diagnosis. Rather, it is something which comes from the very context in which members of first-world countries exist-for example, their cultural perceptions and obsessions with perfect beauty. Eating-disorder sufferers experience fragmentation between their "self" and their body, seeking the control that will give peace and attempting to respond to their heart's deepest desire: to be worthy of love. Even the brief detailing of eating disorders' roots and the suffering they inflict makes clear the centrality of individualism and self. Not only is the sufferer closed in on herself and her world of control (exemplified by her desperate attempts to be enough) and dealing with pain, but she has also forgotten her inherent value derived from her human dignity. Broadly, eucharistic grace reorients the whole person; it reminds the person who she is, that for which she is created, of the depth of Christ's love, and her communal belonging. While eucharistic grace is multifaceted and gently touches many of eating-disorders' wounds, St. Thomas Aquinas' treatment of the Eucharist's unifying nature emphasizes community's ability to draw people out of themselves and reorient them to their primary identity as God's beloved. Beautifully, the Eucharist offers healing through the very manner in which the disorder is realized: eating.

The Eucharist's inherently restorative and unitive nature illustrates the imperative urgency of inviting those who suffer with eating disorders to the eucharistic banquet as a source of healing. According to St. Thomas Aquinas, "the Eucharist exists to nurture the unity of the ecclesial body of Christ." 15 Aquinas details four ways in which the Eucharist effects this unity in the spiritual life of believers: (1) Christ's incarnate presence in the Eucharist mirrors his earthly incarnation, yielding spiritual life which parallels the eternal life won by his passion; (2) the Eucharist is a sign of Christ's passion which effects the forgiveness of sins; (3) as food, the

${ }^{15}$ David Farina Turnbloom, Speaking with Aquinas: A Conversation about Grace, Virtue, and the Eucharist (Collegeville, MN: Liturgical Press, 2017), 35. Aquinas' use of ecclesial is inclusive, encompassing the whole Church community. 
Eucharist "does for the spiritual life all that material food does for the bodily life, namely by sustaining, giving increase, restoring, and giving delight"; (4) the signs of bread and wine represent unity, "composed of many grains/grapes that are formed into one bread/wine." 16 Aquinas' concept of the "spiritual life" is not just mystical, but also historical and rooted in the present; "[t]he body may be mystical, but its unity is not. The unity of the mystical body of Christ is the unity of a Church that lives the spiritual life in its members. The degree to which the mystical body of Christ lives out its spiritual life is the degree to which it is united." ${ }^{17}$ Thus, any lack of unity - specifically here, the crippling isolation of the sufferer from her very self, God, and others - limits the degree to which the Church can live out its spiritual life, its vocation. According to Turnbloom, "Simply put, my union with Christ is inseparable from and ordered toward the community's unity as Christ." ${ }^{18}$ It is the Eucharist which deepens the Church's spiritual life through this unity; that is to say, "[t]he unity of the ecclesial body of Christ, the grace toward which the Eucharist aims, is an increase in the formally active presence of charity in that communal body." ${ }^{\prime 19}$ Eucharistic grace enables the Church, broadly and specifically in the life of each of her members, to live out the vocation of love through charity.

Thus, the ability of both the sufferer and the Church to live out charity is intertwined with the sufferer's healing and restoration to self, God, others, and the Body of Christ. This reality is effected through eating, an action which must be addressed further in light of eating disorder sufferers' affliction. Christ's Body is humanity's primary mode of unification with God; "through participation in the Divine Nature, the human person is moved to recognize and respond to God's friendship." ${ }^{20}$ In the host " the eucharistic body of Christ...is made present as the nourishment who strengthens us to live as Christ lived. In the eucharistic body of Christ, we see the cause, form, and end of our salvation." ${ }^{21}$ Eating Christ compels the sufferer to begin to break her bonds, to remove the scales from her eyes that have formed from various experiences and realities. It empowers her through transformation, a gentle healing of wounds that grants her a new vision, a way of living freely_ - "as Christ lived"- to see herself differently by orienting her to her telos both via Christ's healing eucharistic Body and the Body of Christ that is the Church. Through this gentle transformation, effected from within, she can begin to assume a posture which enables her to see the world, others, and her beloved God differently. She can begin to hear the truth that she is a dignified child of God; her ability

\footnotetext{
16 Turnbloom, Speaking with Aquinas, 35.

17 Turnbloom, 36.

18 Turnbloom, 38.

19 Turnbloom, 37.

20 Turnbloom, 103.

21 Turnbloom, 107.
} 
to perceive herself as an imago Dei is no longer impaired such that she sees an image tarnished beyond recognition.

Aquinas, in the article "Whether the Eucharist is Necessary for Salvation?" states the truth which is at the Eucharist's heart: "Spiritual food changes man into itself." 22 The friendship — with self, others, and even God - that the sufferer cannot find, is brought to her from the inside-out via the very process she has come to hate and tried to commandeer: eating. Her fragmented, dualistic self can be healed into the reality God intended: an integrated vision of body and soul, not two realities at war with each other in the self. The imperfect way in which she has tried to seek peace; to seek reconciliation with herself in order to arrive at worthiness; to reconcile herself to her past, her present, and the world, is perfected not through whiteknuckled conquest, but spiritual nourishment effected materially, sacramentally: "Spiritual nourishment exists to form the eater into itself. Hence, in the Eucharist, perfect charity turns imperfect charity into itself." ${ }^{23}$ Once again, this effect is not merely personal. The Eucharist does not simply restore the individual to herself, leaving her blissfully whole in a halo of singular perfection. Instead, the individual is restored to herself in the context of the Church, the Body of Christ-a context through which restoration is effected, and a reality her wholeness desperately needs and seeks. "As such, eucharistic grace is the communal moral reality of the Church virtuously living the embodied spiritual life. My union with Christ (i.e., spiritually eating the eucharistic body of Christ) is inseparable from and ordered toward the Church's unity as Christ (i.e., the unity of the ecclesial body of Christ)." 24

Eucharistic grace, effected primarily through the act of eating, restores the sufferer to herself. Healing the axes of dualism, control, and gender-power while responding to the lies of a culture pervaded by superficial valuation, the grace of the Eucharist enables the sufferer to regain her sense of self in and through the Body of Christ. Her imperfect attempts to love, to earn, to find peace are transformed by Christ's sacrifice offered to her under the species of bread and wine. Restoring her to the community which can remind her who, what, and whose she is, the Eucharist not only presents God's friendship, but enables the response that she may otherwise find impossible to enact, despite desiring it. Recovering the sacred act of eating, the hated means of control through which she breaks herself, and restoring the sufferer to wholeness can be effected extraordinarily in and through the grace of the Body of Christ.

\footnotetext{
22 Turnbloom, 107.

23 Turnbloom, 110.

24 Turnbloom, 110.
} 


\section{HEEDER: EUCHARISTIC RECONCILIATION}

\section{Bibliography}

Bordo, Susan. Unbearable Weight: Feminism, Western Culture, and the Body, 10th ed. Berkeley: University of California Press, 2003.

Turnbloom, David Farina. Speaking with Aquinas: A Conversation about Grace, Virtue, and the Eucharist. Collegeville, MN: Liturgical Press, 2017. 